\title{
Membangun Aplikasi E-Commerce Dengan Menggunakan PHP dan MySQL
}

\begin{abstract}
Aplikasi perangkat lunak komputer dan Internet telah berkembang pesat pada dasawarsa ini, demikian pula dengan aplikasi web dan browser internet maupun intranet. Aplikasi Ecommerce telah lama berkembang diawali dengan EDI (Electronic Data Interchange) yang telah berkembang dalam lingkup internasional. Dalam makalah ini diuraikan mengenai arsitektur sistem, tool dan konfigurasi yang diperlukan untuk mengimplementasi aplikasi web e-commerce, konsiderasi masalah keamanan sistem, perancangan dari sisi diagram alur aplikasi dan perancangan basis data, serta kode program PHP yang diperlukan untuk implementasi aplikasi ini. Digunakan bahasa pemrograman PHP karena kemudahan dalam pemrograman, dan kelengkapan fitur untuk mengimplementasi sistem e-commerce, kemampuan untuk cross platform, serta kemudahan untuk deployment bagi pengembang aplikasi.
\end{abstract}

Kata kunci : e-commerce 


\title{
Building Application e Commerce \\ By use of PHP and Mysql
}

\begin{abstract}
Computer software application and Internet was effloresce quick on this decade, such too with webbed application and browser is Internet and also Intranet. Application Ecommerce have so long amends started by EDI ( Electronic is Interchange's Data) already effloresce deep international scope. In this paper is untied about system architecture, tool and configuration required just for mengimplementasi web application e commerce, konsiderasi is system security problem, design of of nurginal diagram grooves application and design of data basis, and PHP program code required just for this application implementation. Utilized by PHP programming languages because amenity in mathematics, and feature equipment for mengimplementasi system e commerce, ability for cross is platform, and amenity for deployment for application developer.
\end{abstract}

Key word: e commerce 